\title{
Mutants with Impaired Respiration in Staphylococcus afermentans
}

\author{
By G. F. GAUSE, G. V. KOCHETKOVA AND G. B. VLADIMIROVA \\ Institute of Antibiotics, Academy of Medical Sciences, Moscow, U.S.S.R.
}

(Received 4. April 1962)

\begin{abstract}
SUMMARY
Mutants with small colonies and impaired respiration were induced by 5-fluorouracil in cultures of Staphylococcus afermentans, NCTC 7503. The consumption of oxygen in colourless mutants attained $66-77 \%$, and in mutants with orange colonies $68-77 \%$ of normal values. Inhibitors of protein synthesis (chloramphenicol, tetracycline, chlortetracycline), inhibitors of cell-wall synthesis (penicillin $\mathbf{G}$, phenoxymethylpenicillin), as well as an inhibitor of RNA formation (actinomycin C) affected the growth of the parent and mutant staphylococci to the same extent. On the other hand, inhibitors which affect DNA - namely, degranol, myleran-mannitol and mitomycin C-selectively inhibited the growth of mutant staphylococci with impaired respiration. Mitomycin $\mathrm{C}$ induced irreversible depolymerization of DNA in bacterial cells; colourless mutants were $2 \cdot 7-3.5$ times, and mutants with orange colonies 33-45 times more vulnerable to its action than the parent culture. The extraction of DNA from bacterial cells showed that the capacity of DNA for extraction from a complex with proteins was decreased in colourless mutants by 2.8-2.9 times, and in mutants with orange colonies by $5 \cdot 0-7 \cdot 3$ times.
\end{abstract}

\section{INTRODUCTION}

Mutants with impaired respiration in Staphylococcus aureus, induced by ultraviolet radiation (Gause, Kochetkova \& Vladimirova, 1957), have been studied in some detail (Gause, Kochetkova \& Vladimirova, 1961). These mutants were selectively inhibited by substances which affected the nucleic acids (Gause \& Kochetkova, 1962). In this connexion the induction of mutants with 'small colonies' and impaired respiration in some other species of micrococci, and a comparative investigation of their characters, are highly desirable. Some new results along these lines obtained in the work with Staphylococcus afermentans are described here.

\section{METHODS}

Organisms. The original culture of Staphylococcus afermentans was obtained from the National Collection of Type Cultures-NCTC 7503. It was isolated during the course of a routine examination of an eye swab from an 11-year-old boy in the Public Health Laboratory at Wakefield, Yorkshire, in 1948.

Measurement of bacteriostatic action of chemical agents. The methods used, as well as composition of the nutrient media, were described earlier in this Journal (Gause \& Kochetkova, 1962).

Manometry. Manometric experiments were carried out in a conventional Warburg apparatus under aerobic conditions at $37^{\circ}$. The organisms were grown on 
nutrient agar in Petri dishes for $24 \mathrm{hr}$. at $37^{\circ}$, washed twice on a centrifuge with $0.8 \% \mathrm{NaCl}$, and afterwards suspended in $0 \cdot 8 \% \mathrm{NaCl}$ in the concentration of about $5 \% \mathrm{w} / \mathrm{v}$ (wet weight). The dry weight of bacterial suspensions was also estimated, and used in the calculation of oxygen consumption. Suspensions of bacteria immediately before experiments were diluted ten times with $\mathrm{M} / 15$ phosphate buffer $\left(\mathrm{Na}_{2} \mathrm{HPO}_{4} \cdot 2 \mathrm{H}_{2} \mathrm{O}+\mathrm{KH}_{2} \mathrm{PO}_{4} \cdot 2 \mathrm{H}_{2} \mathrm{O}, \mathrm{pH} 7 \cdot 4\right)$ containing $0 \cdot 5 \%$ of glucose.

Estimation of nucleic acids. Bacteria contained in $100 \mathrm{ml}$. of medium were washed by centrifugation, and ribonucleic acid (RNA) was extracted from sedimented cells by $1.5 \mathrm{ml} .10 \%$ perchloric acid in the cold $\left(-4^{\circ}\right)$ for $17 \mathrm{hr}$. The cells were again washed on the centrifuge with $0.5 \mathrm{ml}$. fresh cold $10 \%$ perchloric acid. The extracts were combined and diluted by an equal volume of $10 \%$ perchloric acid. These extracts did not contain deoxyribonucleic acid (DNA). RNA contents of extracts were estimated by the orcinol test as follows: to $1 \mathrm{ml}$. of the diluted extract were added $2.5 \mathrm{ml} .0 .02 \% \mathrm{FeCl}_{3}$ (in concentrated $\mathrm{HCl}$ ) and $0.15 \mathrm{ml}$. $10 \%$ orcinol (in $95 \%$ EtOH). After the tube contents were mixed, the tube was heated for $15 \mathrm{~min}$. in a boiling water bath, cooled, and read photometrically at $660 \mathrm{~m} \mu$.

After removal of RNA the bacterial cells were extracted with a fresh $1.5 \mathrm{ml}$. portion of $10 \%$ perchloric acid at $90^{\circ}$ for $15 \mathrm{~min}$., and the contents of DNA in the extract were assayed by the diphenylamine method as follows : to $1 \mathrm{ml}$. of extract in a small tube were added $2.5 \mathrm{ml}$. of the diphenylamine reagent (1.0 g. diphenylamine dissolved in $2 \cdot 0 \mathrm{ml}$. conc. $\mathrm{H}_{2} \mathrm{SO}_{4}$ and $98 \mathrm{ml}$. glacial acetic acid), and the tube was placed in a boiling water bath for $10 \mathrm{~min}$. It was cooled and read photometrically at $540 \mathrm{~m} \mu$.

Extraction of DNA by Schmidt \& Thannhauser procedure. The method used was that described by Spirin, Belozersky, Shugaeva \& Vanushin (1957) as a modification of the original procedure (Schmidt \& Thannhauser, 1945). In our experiments $500 \mathrm{mg}$. of dry bacteria (previously washed by alcohol and ether until washings were colourless) were suspended in $4 \mathrm{ml} .0 .5 \mathrm{~N}-\mathrm{NaOH}$, and hydrolysed at $37^{\circ}$ for $18 \mathrm{hr}$. The suspension was then acidified in the cold by $70 \% \mathrm{HClO}_{4}$ to make the total concentration of perchloric acid in the solution equal to 1-2 \%, and then centrifuged in the cold. The solution containing RNA was discarded, and the sediment containing DNA was washed twice with cold $0.2 \mathrm{~N}-\mathrm{HClO}_{4}$, once with alcohol and once with alcohol and ether $(\mathbf{1}+\mathbf{1})$ in the cold, and finally again with the cold $0 \cdot 2 \mathrm{~N}-\mathrm{HClO}_{4}$ to remove alcohol and ether. A volume of $10 \mathrm{ml}$. was used for washing at each stage. The wet sediment was neutralized with a saturated solution of $\mathrm{NaHCO}_{3}$, and then extracted by alkaline ( $\mathrm{pH} \mathrm{8)} 10 \% \mathrm{NaCl}$ on the boiling water bath for $1 \mathrm{hr}$. The concentration of DNA in the extract was estimated spectrophotometrically by the difference of optical densities at 595 and $650 \mathrm{~m} \mu$. Spectrophotometer SF-4 (U.S.S.R.) was used in our work.

\section{RESULTS}

Induction of mutants with impaired respiration. Various mutagenic factors were tried, but positive results were observed only in experiments with 5-fluorouracil. The parent culture of Staphylococcus afermentans 7503 was grown at $37^{\circ}$ in test tubes in nutrient broth containing 60-70 $\mathrm{g}$. 5-fluorouracil/ml., and samples from the tubes were daily streaked in various dilutions on plates of nutrient agar. After 4-5 days of incubation of the culture in broth, the subcultures on plates showed 
the appearance of small colonies of mutants, dispersed among the colonies of normal bacteria. Some of the mutants were growing in the form of sectors in the colonies of normal organisms. Numerous mutants with small colonies were isolated in the course of this work, and classified into two groups: colourless colonies and colonies of orange colour in various shades. Of the former group, mutants 19 and 44 and of the second group mutants $\mathbf{4 2}$ and 22 were used in this study.

Table 1 shows that the consumption of oxygen in colourless mutants attained 66$77 \%$, and in mutants with orange colonies $68-77 \%$ of normal values, i.e. respiration was impaired to the same degree in these mutants.

Table 1. Oxygen consumption by washed cell suspensions of parent and mutant cultures of Staphylococcus afermentans in the presence of glucose

$\begin{array}{lcc} & \begin{array}{c}\text { No. of } \\ \text { experiments }\end{array} & Q_{\mathrm{O}_{2}}{ }^{*} \\ \text { Parent culture } & 12 & \mathbf{8 2 \cdot 5} \\ \text { Mutant 42 (orange colonies) } & 7 & 63 \cdot 3 \\ \text { Mutant 22 (orange colonies) } & 5 & 56 \cdot 2 \\ \text { Mutant 19 (colourless colonies) } & 5 & \mathbf{5 4 \cdot 5} \\ \text { Mutant 44 (colourless colonies) } & 5 & 63 \cdot 9\end{array}$

* The consumption of oxygen in $\mathrm{mm}^{3} / \mathrm{hr}$. calculated for $1 \mathrm{mg}$. dry weight of bacteria.

Effects of inhibitors. Measurement of minimum inhibitory concentrations of various compounds in nutrient broth showed that inhibitors of protein synthesis in the bacterial cell affected the growth of the parent and mutant organisms to the same degree $(0 \cdot 4-0.5 \mu \mathrm{g}$. chloramphenicol $/ \mathrm{ml}$; $0 \cdot 2-0 \cdot 3 \mu \mathrm{g}$. tetracycline $/ \mathrm{ml}$.; 0.4-0.5 $\mu$ g. chlortetracycline $/ \mathrm{ml}$.). Mutant and parent cultures were affected also to the same degree by inhibitors of cell-wall synthesis $(0.03-0.05$ unit penicillin $\mathrm{G} / \mathrm{ml}$.; 0.02-0.03 unit phenoxymethylpenicillin $/ \mathrm{ml}$.), as well as by 5 -fluorouracil. Addition of thymine $(100 \mu \mathrm{g} . / \mathrm{ml}$.) or uracil $(100 \mu \mathrm{g} . / \mathrm{ml}$.) produced no effect upon the inhibitory action of fluorouracil.

We were particularly interested in the analysis of the inhibitory action of actinomycin $\mathrm{C}$ and mitomycin $\mathrm{C}$, as far as these compounds selectively affect the formation of nucleic acids in the bacterial cell. Experiments showed that mitomycin $\mathrm{C}$ selectively inhibited formation of DNA, and actinomycin $\mathrm{C}$ selectively affected synthesis of RNA in the logarithmic phase of growth of Staphylococcus afermentans (Table 2).

It is of interest that actinomycin $\mathrm{C}$ inhibited the growth of parent and mutant cultures of Staphylococcus afermentans to the same degree; the minimal inhibitory concentration in broth attained $0.003-0.004 \mu \mathrm{g} . / \mathrm{ml}$. The estimations were made by the tube dilution method, as described by Gause \& Kochetkova (1962). In distinction from this, the substances selectively affecting DNA formation-namely, mitomycin C, degranol (1,6-bis-( $\beta$-chloroethylamino)-1,6-deoxy- $d$-mannitol), and myleran mannitol (1,6-dimethanesulphonyl- $d$-mannitol) also selectively inhibited the growth of mutants with the impaired respiration (Table 3).

The action of mitomycin $\mathbf{C}$ is of particular interest, since this compound selectively and irreversibly depolymerizes DNA in bacterial cells (Reich, Shatkin \& Tatum, 1961). It is therefore of significance that colourless mutants were 2.7-3.5 times, and mutants with orange colonies 33-45 times more vulnerable to the action 
of this compound than the parent culture. It may be suggested that some alteration in the DNA of mutants with impaired respiration made the cells more vulnerable to the action of mitomycin $\mathrm{C}$, and that these alterations are more fundamental in mutants with orange colonies as compared to colourless mutants.

Table 2. Effect of Mitomycin $C$ and Actinomycin $C$ on the growth and nucleic acid synthesis of Staphylococcus afermentans*

\begin{tabular}{|c|c|c|c|c|}
\hline Compound, $\mu \mathrm{g} . / \mathrm{ml}$. & $\begin{array}{l}\text { Incubation } \\
\text { time, min. }\end{array}$ & $\begin{array}{c}\text { Turbidity, } \\
\boldsymbol{E}_{\mathbf{6 B 0}}\end{array}$ & $\begin{array}{c}\text { RNA } \\
\text { (orcinol reaction) } \\
\boldsymbol{E}_{\mathbf{6 6 0}}\end{array}$ & $\begin{array}{c}\text { DNA } \\
\text { (diphenylamine } \\
\text { reaction) } \\
E_{540}\end{array}$ \\
\hline \multirow[t]{3}{*}{ Control } & 0 & $0 \cdot 190$ & 0.411 & 0.091 \\
\hline & 75 & $0 \cdot 265$ & 0.481 & $0 \cdot 113$ \\
\hline & 150 & 0.337 & 0.578 & $0 \cdot 132$ \\
\hline \multirow[t]{3}{*}{ Mitomycin C, $0 \cdot 1$} & 0 & $0 \cdot 190$ & 0.4111 & 0.091 \\
\hline & 75 & 0.270 & 0.487 & 0.086 \\
\hline & 150 & $0 \cdot 342$ & 0.577 & 0.088 \\
\hline \multirow[t]{3}{*}{ Control } & $\mathbf{0}$ & $0 \cdot 171$ & 0.399 & 0.085 \\
\hline & 90 & 0.261 & 0.477 & $0 \cdot 109$ \\
\hline & 180 & $0 \cdot 369$ & 0.581 & $0 \cdot 136$ \\
\hline \multirow[t]{3}{*}{ Actinomycin C, 0.1 } & $\mathbf{0}$ & $0 \cdot 171$ & 0.399 & $0 \cdot 085$ \\
\hline & 90 & 0.209 & 0.359 & 0.092 \\
\hline & 180 & 0.259 & 0.372 & $0 \cdot 109$ \\
\hline
\end{tabular}

* The content of RNA and DNA in the microbial cells are given per $100 \mathrm{ml}$. of the culture. Turbidity $E_{600}$ is proportional to the dry weight of bacteria. The figures give the average data of 3 series of experiments. Growth at $37^{\circ}$ in Erlenmeyer's flasks. To $180 \mathrm{ml}$. of nutrient broth were added $20 \mathrm{ml}$. of $18 \mathrm{hr}$. culture of bacteria, and kept at $37^{\circ}$ for $90 \mathrm{~min}$. At this time compounds were added and the first sample taken, marked as ' 0 time'. For each analysis two samples of $50 \mathrm{ml}$. each were taken from two duplicate flasks, and mixed to make $100 \mathrm{ml}$.

Table 3. Minimal growth inhibitory concentrations ( $\mu \mathrm{g} . / \mathrm{ml}$.) of various compounds in nutrient broth for Staphylococcus afermentans and its mutants*

$\begin{array}{lccccc}\text { Compound } & \text { Parent } & \begin{array}{c}\text { Mutant 42 } \\ \text { (orange) }\end{array} & \begin{array}{c}\text { Mutant 22 } \\ \text { (orange) }\end{array} & \begin{array}{c}\text { Mutant 19 } \\ \text { (colourless) }\end{array} & \begin{array}{c}\text { Mutant 44 } \\ \text { (colourless) }\end{array} \\ \text { tomycin C } & \mathbf{0 . 0 5 0 0} & \mathbf{0 . 0 0 1 5} & \mathbf{0 . 0 0 1 1} & \mathbf{0 . 0 1 4 0} & \mathbf{0 . 0 1 8 0} \\ \text { egranol } & \mathbf{2 1 0} & \mathbf{2 2} & \mathbf{2 8} & \mathbf{2 5} & \mathbf{2 9} \\ \text { yleran-mannitol } & \mathbf{4 0 0 0} & \mathbf{6 2 0} & \mathbf{5 2 0} & \mathbf{6 2 0} & \mathbf{4 1 0}\end{array}$

* The conditions of assays were described by Gause \& Kochetkova (1962).

Differences in the DNA-protein relationship of normal and mutant organisms. The extraction of DNA from bacterial cells by Schmidt and Thannhauser procedure (in the modification described by Spirin et al. 1957; see Methods) showed that the average activity of extracts $\left(D_{595}-D_{650}\right)$ in the parent culture attained $0 \cdot 262$, in mutant 19 (colourless) 0.094 , in mutant 44 (colourless) 0.090 , in mutant 42 (orange) $0 \cdot 036$, and in mutant 22 (orange) 0.052 . In other words the capacity of DNA for extraction from a complex with proteins was decreased in colourless mutants by $2 \cdot 8-$ $2 \cdot 9$ times, and in mutants with orange colonies by $5 \cdot 0-7 \cdot 3$ times.

Our observations refer to mild separation of DNA from proteins by extraction at pH 8 by $10 \% \mathrm{NaCl}$, as prescribed by Schmidt \& Thannhauser (1945). In distinction from this. an acid hvdrolysis by $0.5 \mathrm{~N}-\mathrm{HClO}$ at $70^{\circ}$ for $20 \mathrm{~min}$. (Ogur \& Rosen, 1950) 
completely separates DNA from proteins in normal and mutant cells of Staphylococcus afermentans, and differences between these cultures are no longer observed. It is difficult at present to interpret these observations, but it is interesting that Kirby (1961) found recently some differences in the DNA-protein complexes of normal and cancer cells.

We are indebted to Dr S. T. Cowan for a culture of Staphylococcus afermentans and to $\mathrm{Dr}$ J. W. Lightbown for helpful discussions.

\section{REFERENCES}

Gause, G. F., Kochetkova, G. V. \& Vladimirova, G. B. (1957). Biochemical mutants of staphylococci with impaired respiration. Dokl. Acad. Sci. U.S.S.R., 117, 720.

Gause, G. F., Kochetrova, G. V. \& Vladimirova, G. B. (1961). Biochemical changes accompanying impaired respiration in staphylococci. Nature, Lond. 190, 978.

Gause, G. F. \& Kochetrova, G. V. (1962). Vulnerability of nucleic acids in mutant staphylococci. J. gen. Microbiol. 29, 317.

KIRBY, K. S. (1961). Nucleic acids and cancer. Progr. exp. Tumor Res. 2, 291.

Ogur, M. \& Rosen, G. (1950). The nucleic acids of plant tissues. I. The extraction and estimation of deoxypentose nucleic acid and pentose nucleic acid. Arch. Biochem. 25, 262.

Reich, E., Shatkin, A. J. \& Tatum, E. L. (1961). Bactericidal action of mitomycin C. Biochim. biophys. Acta, 53, 132.

Schmidt, G. \& Thannhauser, S. J. (1945). A method for the determination of deoxyribonucleic acid, and phosphoproteins in animal tissues. J. biol. Chem. 161, 83.

Spirin, A. S., Belozersky, A. N., Shugaeva, N. V. \& Vanushin, B. F. (1957). A study of species specificity of nucleic acids in bacteria. Biokhimia (Moscow), 22, 744 . 